Abstracta Iranica Abstracta Iranica

Revue bibliographique pour le domaine irano-aryen

Volume 30 | 2010

Comptes rendus des publications de 2007

\title{
« Understanding the Insurgency in Afghanistan ». Orbis, Vol. 51, N 1 , hiver 2007, pp. 71-89.
}

\section{Anicée Van Engeland}

\section{(2) OpenEdition}

1 Journals

\section{Édition électronique}

URL : http://journals.openedition.org/abstractairanica/38167

DOI : 10.4000/abstractairanica.38167

ISSN : 1961-960X

Éditeur :

CNRS (UMR 7528 Mondes iraniens et indiens), Éditions de l'IFRI

\section{Édition imprimée}

Date de publication : 8 avril 2010

ISSN : 0240-8910

\section{Référence électronique}

Anicée Van Engeland, « "Understanding the Insurgency in Afghanistan ». Orbis, Vol. 51, N1, hiver 2007, pp. 71-89. », Abstracta Iranica [En ligne], Volume 30 | 2010, document 333, mis en ligne le 08 avril 2010, consulté le 05 octobre 2020. URL : http://journals.openedition.org/abstractairanica/38167 ; DOI : https://doi.org/10.4000/abstractairanica.38167

Ce document a été généré automatiquement le 5 octobre 2020.

Tous droits réservés 


\section{« Understanding the Insurgency in Afghanistan ». Orbis, Vol. 51, $\mathrm{N}^{\circ} 1$, hiver 2007, pp. 71-89.}

\section{Anicée Van Engeland}

1 Au lieu de s'intéresser aux causes de l'insécurité, les AA. examinent les acteurs de cette crise: les taliban. L'article analyse les techniques insurrectionnelles des taliban et les comparent à celles utilisées en Irak. L'approche simpliste du taliban est dépassée pour comprendre les structures claniques et le soutien provincial à ces troupes. Les composantes islamiques et tribales du groupe sont analysées ainsi que la base sociologique du taliban. Enfin là où les taliban mènent une guerre asymétrique, la coalition suit son plan initial et de fait perd les villages pashtoun les uns après les autres. Cet article est donc original dans le sens où il présente un portrait de l'ennemi de la coalition.

\section{INDEX}

Thèmes : 13.2. Afghanistan

\section{AUTEURS}

\section{ANICÉE VAN ENGELAND}

European University Institute - Florence 